\title{
Novelty of Active Ingredients in High-Cost Brand-Name Drugs
}

\author{
Emily H. Jung, A. B. ${ }^{7}$, Ameet Sarpatwari, J.D., Ph.D. ${ }^{\text {, }}$ \\ and Aaron S. Kesselheim, M.D., J.D., M.P.H. ${ }^{7}$
}

'Program On Regulation, Therapeutics, And Law (PORTAL), Division of Pharmacoepidemiology and Pharmacoeconomics, Department of Medicine, Brigham and Women's Hospital and Harvard Medical School, Boston, MA, USA.

J Gen Intern Med 35(7):2219-2 1

DOI: $10.1007 / \mathrm{s} 11606-019-05565-8$

(c) Society of General Internal Medicine 2019

I n 2017, prescription drugs accounted for about one-fifth of Medicare spending, with expenditures for the Part D outpatient drug insurance program totaling $\$ 94$ billion. ${ }^{1}$ In 2016 , $84 \%$ of Part D spending came from brand-name drugs, which made up $14 \%$ of prescriptions overall. ${ }^{2,3}$ Since a common justification for the high prices of brand-name products is that they are needed to sustain new drug development, we examined the novelty of active ingredients in the 25 brand-name drugs with the highest Medicare Part D spending in 2017, which accounted for $30 \%$ of total Part D spending that year.

\section{METHODS}

We used the Centers for Medicare and Medicaid Services Medicare Part D Drug Spending Dashboard to identify the 25 brand-name drugs with the highest spending in 2017, the most recent year for which data were available. Consulting the Drugs@FDA database and FDA Orange Book, we identified the drugs' active ingredients and approval dates of all brandname products containing the ingredients. We additionally searched whether the ingredients had been approved in generic or biosimilar products (as of June 18, 2019) and, if so, when. We calculated the median time between approval of the earliest brand-name drugs containing the active ingredients and December 31, 2017.

\section{RESULTS}

Among the 27 active ingredients identified -22 single active ingredient products, 3 combination products, and 2 products containing the same active ingredient-11 (41\%) had

Received October 2, 2019

Revised October 2, 2019

Accepted November 20, 2019

Published online January 2, 2020 previously been approved by the FDA in other formulations or products (Table 1).

Of these 11 active ingredients, the median time between FDA approval of their first products and the end of 2017 was 19.2 years (interquartile range [IQR] 16.3-23.9). Six active ingredients were first available in products with different dosage forms or delivery devices. For example, etanercept and insulin aspart were originally marketed as solutions sold in vials in 1998 and 2000, respectively. Two ingredients were first approved in products with similar indications to the drugs in our cohort. For example, the combination of fluticasone and salmeterol in Advair Diskus is indicated for asthma and chronic obstructive pulmonary disease (COPD), while salmeterol alone, first approved in 1994 (Serevent), is indicated for asthma, COPD, and prevention of exercise-bronchospasm. Three ingredients were initially approved in products with different indications. For example, cyclosporine in Restasis eye drops (for dry eyes) was originally approved as Sandimmune (capsule, injectable, and solution) for prophylaxis of transplant organ rejection in 1983 (Fig. 1).

Among the other $16(59 \%)$ active ingredients that were first FDA-approved as one of the products in our sample, the median time between FDA approval and the end of 2017 was 9.1 years (IQR 4.9-12.3). Eight of the 16 ingredients have been available for longer than a decade.

Six $(22 \%)$ of the 27 active ingredients have been FDAapproved in generic or biosimilar products therapeutically equivalent to the brand-name products in our cohort. Two of these six ingredients were first approved in products in 2000 or earlier. Of the 21 ingredients unavailable in therapeutically equivalent products, three were approved in insulin drugs for diabetes and three were approved in inhalers for asthma and COPD. These six ingredients were first approved in 2000 or earlier.

\section{DISCUSSION}

Many active ingredients in the 25 brand-name drugs with the highest Medicare spending were discovered decades ago, with a substantial minority having been previously marketed in alternative formulations or products. 
Table 1 Active Ingredients in Brand-Name Drugs with the Highest Medicare Part D Spending in 2017

\begin{tabular}{|c|c|c|c|c|c|c|}
\hline $\begin{array}{l}\text { Active } \\
\text { ingredient(s) }\end{array}$ & $\begin{array}{l}\text { Brand-name product } \\
\text { (dosage form; route of } \\
\text { administration) } \\
\text { [manufacturer] }\end{array}$ & $\begin{array}{l}\text { Approval } \\
\text { date of } \\
\text { brand- } \\
\text { name } \\
\text { product }\end{array}$ & $\begin{array}{l}2017 \text { Average } \\
\text { Medicare } \\
\text { spending per } \\
\text { beneficiary (on } \\
\text { the brand-name } \\
\text { product) }\end{array}$ & 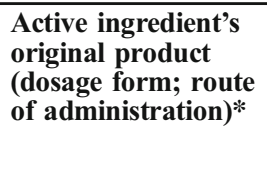 & $\begin{array}{l}\text { Approval date of } \\
\text { earliest brand- } \\
\text { name product } \\
\text { containing active } \\
\text { ingredient(s) }\end{array}$ & $\begin{array}{l}\text { Approval } \\
\text { date of } \\
\text { earliest } \\
\text { generic or } \\
\text { biosimilar } \\
\text { product }\end{array}$ \\
\hline Adalimumab & $\begin{array}{l}\text { Humira Pen (injectable; } \\
\text { subcutaneous) [Abbott] }\end{array}$ & $6 / 23 / 2006$ & $\$ 38,888$ & $\begin{array}{l}\text { Humira (syringe; } \\
\text { subcutaneous and } \\
\text { vial; subcutaneous) }\end{array}$ & $12 / 31 / 2002$ & $9 / 23 / 2016$ \\
\hline Apixaban & $\begin{array}{l}\text { Eliquis (tablet; oral) [Bristol- } \\
\text { Myers Squibb] }\end{array}$ & $12 / 28 / 2012$ & $\$ 2692$ & $\checkmark$ & $12 / 28 / 2012$ & $\begin{array}{l}6 / 28 / 2018 \\
(\text { tentative })^{\mathrm{II}}\end{array}$ \\
\hline $\begin{array}{l}\text { Budesonide } \\
\text { and } \\
\text { formoterol }\end{array}$ & $\begin{array}{l}\text { Symbicort }{ }^{\#} \text { (aerosol, metered; } \\
\text { inhalation) [AstraZeneca] }\end{array}$ & $7 / 21 / 2006$ & $\$ 1516$ & $\checkmark^{\dagger}$ & $\begin{array}{l}2 / 14 / 1994 \\
\text { (Budesonide) and } \\
7 / 21 / 2006 \\
\text { (Formoterol) }\end{array}$ & - \\
\hline Cinacalcet & Sensipar (tablet; oral) [Amgen] & $3 / 8 / 2004$ & $\$ 9302$ & $\checkmark$ & $3 / 8 / 2004$ & $3 / 8 / 2018$ \\
\hline Cyclosporine & $\begin{array}{l}\text { Restasis }{ }^{\#} \text { (emulsion; } \\
\text { ophthalmic) [Allergan] }\end{array}$ & $12 / 23 / 2002$ & $\$ 1856$ & $\begin{array}{l}\text { Sandimmune } \\
\text { (injectable; injection, } \\
\text { solution; oral and } \\
\text { capsule; oral) }\end{array}$ & $11 / 14 / 1983$ & - \\
\hline $\begin{array}{l}\text { Dimethyl } \\
\text { fumarate }\end{array}$ & $\begin{array}{l}\text { Tecfidera (capsule, delayed } \\
\text { release; oral) [Biogen] }\end{array}$ & $3 / 27 / 2013$ & $\$ 60,047$ & $\checkmark$ & $3 / 27 / 2013$ & $\begin{array}{l}8 / 17 / 2018 \\
\text { (tentative) }^{\mathrm{II}}\end{array}$ \\
\hline Etanercept & $\begin{array}{l}\text { Enbrel Sureclick (injectable; } \\
\text { subcutaneous) [Immunex] }\end{array}$ & $6 / 14 / 2006^{\| \prime}$ & $\$ 36,177$ & $\begin{array}{l}\text { Enbrel (syringe; } \\
\text { subcutaneous and } \\
\text { vial; subcutaneous) }\end{array}$ & $11 / 2 / 1998$ & $8 / 30 / 2016$ \\
\hline $\begin{array}{l}\text { Fluticasone } \\
\text { and salmeterol }\end{array}$ & $\begin{array}{l}\text { Advair Diskus }{ }^{\#} \text { (powder; } \\
\text { inhalation) [GlaxoSmithKline] }\end{array}$ & $8 / 24 / 2000$ & $\$ 2091$ & $S^{\ddagger}$ & $\begin{array}{l}12 / 14 / 1990 \\
\text { (Fluticasone) and } \\
2 / 4 / 1994 \\
\text { (Salmeterol) }\end{array}$ & - \\
\hline Glatiramer & $\begin{array}{l}\text { Copaxone (injectable; } \\
\text { subcutaneous) [Teva] }\end{array}$ & $12 / 20 / 1996$ & $\$ 57,296$ & $\checkmark$ & $12 / 20 / 1996$ & $4 / 16 / 2015$ \\
\hline Ibrutinib & $\begin{array}{l}\text { Imbruvica (capsule; oral and } \\
\text { tablet; oral) [Pharmacyclis] }\end{array}$ & $11 / 13 / 2013$ & $\$ 73,022$ & $\checkmark$ & $11 / 13 / 2013$ & - \\
\hline Insulin aspart & $\begin{array}{l}\text { Novolog Flexpen (injectable; } \\
\text { subcutaneous) [Novo Nordisk] }\end{array}$ & $1 / 19 / 2001$ & $\$ 2804$ & $\begin{array}{l}\text { Novolog (injectable; } \\
\text { subcutaneous) }\end{array}$ & $6 / 7 / 2000$ & - \\
\hline $\begin{array}{l}\text { Insulin } \\
\text { detemir }\end{array}$ & $\begin{array}{l}\text { Levemir Flextouch (injectable; } \\
\text { subcutaneous) [Novo Nordisk] }\end{array}$ & $10 / 31 / 2013$ & $\$ 2757$ & $\begin{array}{l}\text { Levemir (injectable; } \\
\text { subcutaneous) }\end{array}$ & $6 / 16 / 2005$ & - \\
\hline $\begin{array}{l}\text { Insulin } \\
\text { glargine }\end{array}$ & $\begin{array}{l}\text { Lantus Solostar (injectable; } \\
\text { injection) [Sanofi Aventis] }\end{array}$ & $4 / 27 / 2007$ & $\$ 2366$ & $\begin{array}{l}\text { Lantus (injectable; } \\
\text { injection) }\end{array}$ & $4 / 20 / 2000$ & - \\
\hline $\begin{array}{l}\text { Insulin } \\
\text { glargine }\end{array}$ & $\begin{array}{l}\text { Lantus (injectable; injection) } \\
\text { [Sanofi Aventis] }\end{array}$ & $4 / 20 / 2000$ & $\$ 2528$ & $\checkmark$ & $4 / 20 / 2000$ & - \\
\hline Insulin lispro & $\begin{array}{l}\text { Humalog Kwikpen (injectable; } \\
\text { injection) [Eli Lilly] }\end{array}$ & $9 / 6 / 2007$ & $\begin{array}{l}(\mathrm{U}-100) \$ 2628 \\
(\mathrm{U}-200) \$ 3993\end{array}$ & $\begin{array}{l}\text { Humalog (injectable; } \\
\text { injection) }\end{array}$ & $6 / 14 / 1996$ & - \\
\hline $\begin{array}{l}\text { Ledipasvir } \\
\text { and } \\
\text { Sofosbuvir }\end{array}$ & Harvoni (tablet; oral) [Gilead] & $10 / 10 / 2014$ & $\$ 78,891$ & $\sqrt{s}^{s}$ & $\begin{array}{l}\text { 10/10/2014 } \\
\text { (Ledipasvir) and } \\
12 / 6 / 2013 \\
\text { (Sofosbuvir) }\end{array}$ & - \\
\hline Lenalidomide & $\begin{array}{l}\text { Revlimid (capsule; oral) } \\
\text { [Celgene] }\end{array}$ & $12 / 27 / 2005$ & $\$ 88,437$ & $\checkmark$ & $12 / 27 / 2005$ & - \\
\hline Liraglutide & $\begin{array}{l}\text { Victoza (solution; } \\
\text { subcutaneous) [Novo Nordisk] }\end{array}$ & $1 / 25 / 2010$ & $\begin{array}{l}\text { (2-pak) } \$ 2405 \\
\text { (3-pak) \$4799 }\end{array}$ & $\checkmark$ & $1 / 25 / 2010$ & - \\
\hline Lurasidone & Latuda (tablet; oral) [Sunovion] & $10 / 28 / 2010$ & $\$ 8866$ & $\checkmark$ & $10 / 28 / 2010$ & $1 / 3 / 2019$ \\
\hline Palbociclib & Ibrance (capsule; oral) [Pfizer] & $2 / 3 / 2015$ & $\$ 68,466$ & $\checkmark$ & $2 / 3 / 2015$ & \\
\hline Pregabalin & $\begin{array}{l}\text { Lyrica (capsule; oral and } \\
\text { solution; oral) [Pfizer] }\end{array}$ & $12 / 30 / 2004$ & $\$ 2872$ & $\checkmark$ & $12 / 30 / 2004$ & $\begin{array}{l}9 / 26 / 2012 \\
\text { (tentative) }^{\mathrm{II}}\end{array}$ \\
\hline Rivaroxaban & Xarelto (tablet; oral) [Janssen] & 7/1/2011 & $\$ 2741$ & $\checkmark$ & 7/1/2011 & \\
\hline Sevelamer & $\begin{array}{l}\text { Renvela (tablet; oral and for } \\
\text { suspension; oral) [Genzyme] }\end{array}$ & $10 / 19 / 2007$ & $\$ 7156$ & $\checkmark$ & $10 / 19 / 2007$ & $6 / 13 / 2017$ \\
\hline Sitagliptin & Januvia (tablet; oral) [Merck] & $10 / 16 / 2006$ & $\$ 3118$ & $\checkmark$ & $10 / 16 / 2006$ & $\begin{array}{l}10 / 10 / 2012 \\
\text { (tentative }^{\mathrm{II}}\end{array}$ \\
\hline Tiotropium & $\begin{array}{l}\text { Spiriva (powder; inhalation) } \\
\text { [Boehringer Ingelheim] }\end{array}$ & $1 / 30 / 2004$ & $\$ 2315$ & $\checkmark$ & $1 / 30 / 2004$ & - \\
\hline
\end{tabular}

*A checkmark $(\checkmark)$ indicates that the active ingredient(s) was first FDA-approved in the corresponding brand-name product in our cohort. For ingredients that were first approved in a different product, the name of the original product is listed

†Approved on 7/21/2006, Symbicort was the first drug containing the combination of both budesonide and formoterol. Budesonide was first approved in the product Rhinocort and formoterol was first approved in the product Symbicort

$\$$ Approved on 8/24/2000, Advair Diskus was the first drug containing the combination of both fluticasone and salmeterol. Fluticasone was first approved in the product Cutivate and salmeterol was first approved in the product Serevent

${ }^{\S}$ Approved on 10/10/2014, Harvoni was the first drug containing the combination of both ledipasvir and sofosbuvir. Ledipasvir was first approved in the product Harvoni and sofosbuvir was first approved in the product Sovaldi

"The approval date of Enbrel Sureclick is publicly unavailable. The date of the earliest drug label containing information about Sureclick is listed

"Tentative approval" means that the product meets the requirements for FDA approval however is unable to receive final approval due to unexpired patents or exclusivity periods

\#Approved indications of the product in our cohort and the original product differ for Symbicort/Rhinocort (asthma/rhinitis), Restasis/Sandimmune (dry eyes/transplant rejection), and Advair Diskus/Cutivate (chronic obstructive pulmonary disease/dermatoses) 


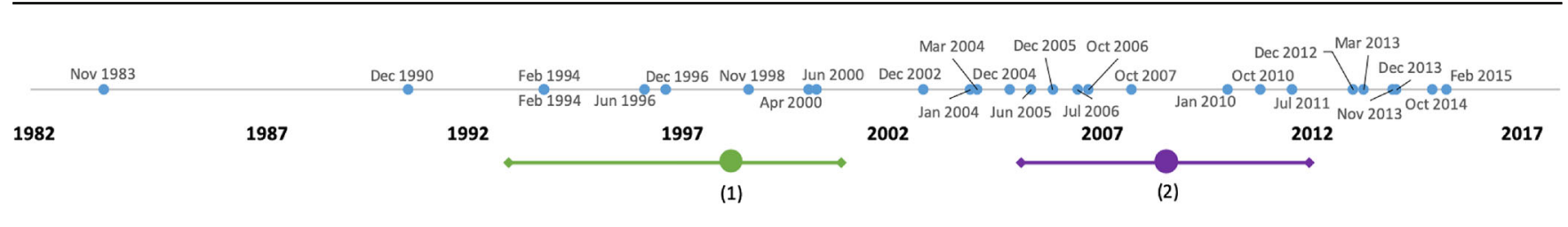

Figure 1 Earliest FDA approval dates corresponding to the 27 active ingredients. Timeline displaying the dates (month, year) of FDA approvals of the earliest products containing the $\mathbf{2 7}$ active ingredients for the drugs studied. The median approval year for the eleven active ingredients that had been first FDA-approved in other formulations or products was 1998 (IQR 1993-2001) (point 1, in green). The median approval year for the sixteen active ingredients that had been first FDA-approved in one of the products in our cohort was 2008 (IQR 2005-2012) (point 2, in purple). Error bars represent interquartile ranges.

Repurposing already approved drugs in new formulations, drug-device combinations, or for new indications is a less costly form of drug innovation, because preclinical work and early-phase clinical trials may be streamlined, and is also less risky for sponsors. ${ }^{4}$ High Medicare spending on such older products is facilitated by patents on new delivery devices or formulations, which can protect against entry of low-cost generic versions. ${ }^{5}$

In recent months, legislators and regulators have announced plans to encourage availability of alternative production of insulins to improve competition and lower prices in that market, including the potential role for a government manufacturer. ${ }^{6}$ In addition to insulin, policymakers should examine all of the high-cost drugs in our cohort -17 of 25 which had active ingredients first FDA-approved more than a decade ago and 15 of 25 which do not have therapeutic equivalents - to determine why generic or biosimilar versions are not yet on the market and how to take steps to facilitate entry for the benefit of patients and reduce unnecessary Medicare spending.

Corresponding Author: Aaron S. Kesselheim, M.D., J.D., M.P.H.; Program On Regulation, Therapeutics, And Law (PORTAL), Division of Pharmacoepidemiology and Pharacoeconomics, Department of Medicine, Brigham and Women's Hospital and Harvard Medical School, Boston, MA, USA (e-mail: akesselheim@partners.org).
Funding Information This study was funded by Arnold Ventures. Dr. Kesselheim's work is additionally supported by the Harvard-MIT Center for Regulatory Science and the Engelberg Foundation.

\section{REFERENCES}

1. Medicare Payment Advisory Commission (MedPAC). Report to the Congress: Chapter 14, The Medicare prescription drug program (Part D): Status report. March 2019. Available at http://www.medpac.gov/docs/ default-source/reports/mar19_medpac_ch14_sec.pdf?sfvrsn=0. Accessed 20 August 2019.

2. Centers for Medicare \& Medicaid Services. Medicare Part D Drug Spending Dashboard and Data. 14 March 2019. Available at https://www.cms.gov/ Research-Statistics-Data-and-Systems/Statistics-Trends-and-Reports/Information-on-Prescription-Drugs/MedicarePartD.html. Accessed $20 \mathrm{Au}$ gust 2019.

3. U.S. Department of Health and Human Services. Savings Available Under Full Generic Substitution of Multiple Source Brand Drugs in Medicare Part D. 23 July 2018. Available at https://aspe.hhs.gov/system/files/pdf/ 259326/DP-Multisource-Brands-in-Part-D.pdf. Accessed 20 August 2019.

4. Pantiziarka P, Pirmohamed M, Mirza N. New uses for old drugs. BMJ. 2018;361:k2701.

5. Beall RF, Kesselheim AS. Tertiary patenting on drug-device combination products in the United States. Nat Biotechnol. 2018;36(2):142-5.

6. Scott D. Elizabeth Warren's ambitious new bill to lower generic drugs prices, explained. Vox. 20 December 2018. Available at https://www.vox. com/policy-and-politics/2018/12/20/18146993/elizabeth-warren-2020election-drug-prices-bill. Accessed 11 August 2019.

Publisher's Note Springer Nature remains neutral with regard to jurisdictional claims in published maps and institutional affiliations. 